geophysical consultants, NEGEM Ltd., London, and Olexcon International N.V., The Hague.

Survey members have assisted companies holding concession rights with maps and other basic material as and when requested. The Survey's report archives containing results and notes of field work undertaken by the Survey is available to companies for reference.

In cooperation with the Danish Atomic Energy Commission's Research Establishment at Ris $\phi$, work was continued on the evaluation of the radioactive mineral content of the Ilímaussaq alkaline intrusion in South Greenland as well as on the processing and interpretation of aeroradiometric data in terms of radioactive mineral distribution in the Scoresby Sund region of central East Greenland.

Note

The following 18 articles report the principal field activities in Greenland in 1972, together with the main results of isotopic age determination work carried out on Survey material during the year, and with other laboratory investigations. Articles dealing with North Greenland and central West Greenland come first, followed by those from southern West Greenland, South Greenland and East Greenland. Compilations of isotopic work and radiocarbon dating on material throughout Greenland conclude the report.

Unless otherwise stated at the end of each article, the author's address is the Survey's headquarters in Copenhagen.

\title{
ORDOVICIAN AND SILURIAN FAUNAS FROM NORTHERN PEARY LAND, NORTH GREENLAND
}

\section{Merete Bjerreskov and Valdemar Poulsen}

Fossiliferous samples were collected from the North Greenland fold belt by P. R. Dawes and N. J. Soper during reconnaissance mapping in 1969. In a preliminary report (Dawes \& Soper, 1970) an Ordovician age was suggested for graptolite shales at O. B. B $\emptyset$ ggild Fjord and Harebugt, the age being based on faunal content, and the association with intraformational limestone breccias bearing a striking resemblance to the Ordovician succession in the western part of the fold belt in Nyeboe Land. A shelly fauna from Frederick E. Hyde Fjord was referred to the Silurian.

The fossiliferous samples were presented to the present authors for further study. This report summarises the fauna from Dawes \& Soper's (1970) localities F1 to F5. 
Lower Ordovician graptolites by Merete Bjerreskov

Locality F1, Kap Bopa

GGU sample 53485

Thirty-six dark-weathered shale fragments collected from a folded intercalated sandstone-shale sequence, not in situ. The graptolites are mainly flattened and tectonically compressed. Occasionally the graptolites appear as moulds with preserved relief. The fauna comprises: Goniograptus sp., Tetragraptus quadribrachiatus (J. Hall), Tristichograptus ensiformis (J. Hall); Didymograptus sp., Cardiograptus folium Ruedemann, Isograptus caduceus lunata (Harris), I. caduceus lunatal victoriae, I. caduceus (Salter), ?"Isograptus" manibriatus (T. S. Hall), Skiagraptus?, ?Paraglossograptus tentaculatus (J. Hall) (junior synonym is Hallograptus etheridgei (Harris) (Rickards, 1972)), ?Glyptograptus.

Locality F2, northern coast, head of O. B. Bøggild Fjord GGU sample 53488

Thirty-six shale fragments collected in situ from a unit of shales and silicified siltstones. The graptolites are preserved in the black shale and are flattened or in low relief, rather compressed. The following graptolites occur: Clonograptus sp., Tetragraptus approximatus (Nicholson), Tetragraptus quadribrachiatus?, Tetragraptus aff. T. decipiens (T. S. Hall), Didymograptus novus Berry?, Didymograptus sp.

GGU sample 53494.

One piece of silicified shale with graptolites collected in loose material from black calcareous shale. The graptolites are flattened. The sample contains: Tetragraptus aff. T. approximatus, Tetragraptus cf. T. fructicosus (Hall), Didymograptus?.

Locality F3, north of Harebugt

GGU sample 53489

One piece of silicified shale collected in situ from folded mainly well-bedded shales. The graptolites are flattened and slightly tectonically compressed. Two specimens of Isograptus caduceus have been observed.

\section{GGU sample 53491}

Seventeen samples with graptolites collected in situ from a unit of calcareous siltstone, chert and shales. Most of the graptolites preserved in the black shales are flattened, some stipes are partly in relief. The graptolites are slightly compressed. The fauna contains: ?Dictyonema, Clonograptus flexilis (Hall), Clonograptus rigidus (Hall), Tetragraptus approximatus, Tetragraptus quadribrachiatus, Tetragraptus aff. T. decipiens. 


\section{GGU sample 53492}

One piece of shale collected in situ from dark grey calcareous siltstone and shale succession. The graptolites are flattened and slightly compressed. The graptolites are: Didymograptus?, Isograptus caduceus divergens Harris, I. caduceus, Skiagraptus gnomonicus (Harris \& Keble), Glossograptus n.sp.

\section{Age of the fauna}

The graptolites identified are of Lower Ordovician age and mainly restricted to two graptolite zones. The assemblages from O. B. Bøggild Fjord, GGU 53488 and GGU 53494, and Harebugt, GGU 53491, indicate the presence of the Tetragraptus approximatus Zone. Characteristic of the zone is $T$. approximatus in association with Clonograptus and the presence of the earliest extensiform didymograptids (see Kindle \& Whittington, 1958; Berry, 1960). The T. approximatus Zone is reported from North America, Australia, China and Scandinavia, but is not formally recognised in Great Britain. The graptolite faunas correlate with beds just below the British Didymograptus deflexus Zone, early Arenigian.

The samples from Harebugt, GGU 53489 and GGU 53492, and from Kap Bopa, GGU 53485, contain a graptolite fauna indicative of the Isograptus caduceus Zone corresponding to the zones 8-9 of Berry (1960) in North America. The index fossil $I$. caduceus with subspecies are associated with important graptolites as Tristichograptus ensiformis, Skiagraptus gnomonicus, Cardiograptus folium and ?Paraglossograptus tentaculatus.

The subspecies of $I$. caduceus (lunata and lunata/victoriae) are referred to the Castlemaine Stage in the Australian sequence, corresponding to the later Arenigian Isograptus gibberulus Zone in Great Britain. Tristichograptus ensiformis, Cardiograptus, Skiagraptus and Isograptus caduceus divergens are referred to the Yapeen Stage in Australia, which approximately corresponds to the British Didymograptus hirundo Zone, uppermost Arenigian.

Unfortunately the specimens, making up sample GGU 53485, which through correlation with other sequences may be assigned to different levels in the $I$. caduceus Zone, were not collected in situ and consequently no information is available with regard to the successive development of the graptolite fauna in this zone.

In the zone of Isograptus caduceus the presence of Cardiograptus', Skiagraptus and ?Paraglossograptus, which are endemic genera for the "Pacific" graptolite fauna (Skevington, 1968), and the dominance of the isograptids indicate that the graptolite fauna in the eastern part of the North Greenland fold belt might be referred to the "Pacific" Lower Ordovician graptolite fauna. The "Pacific" graptolite fauna includes Lower Ordovician graptolites reported from Australia, North America (e.g. Texas, Yukon and Newfoundland), China, western Ireland and the Trondheim region in Norway, whereas the "Atlantic" graptolite faunas are mainly developed in north-western England, Wales and northern Europe (Skevington, 1968; Dewey et al., 1970). 
Lower Silurian shelly fauna by Valdemar Poulsen

\section{Locality F4, south coast Frederick E. Hyde Fjord, east of Thors Fjord} GGU samples 53495-53523, 53525-53527

The samples were collected from a 10-12 $\mathrm{m}$ thick limestone layer associated with intraformational conglomerate, within a sequence of shales and calcareous sandstone. The fauna includes the following previously known species:

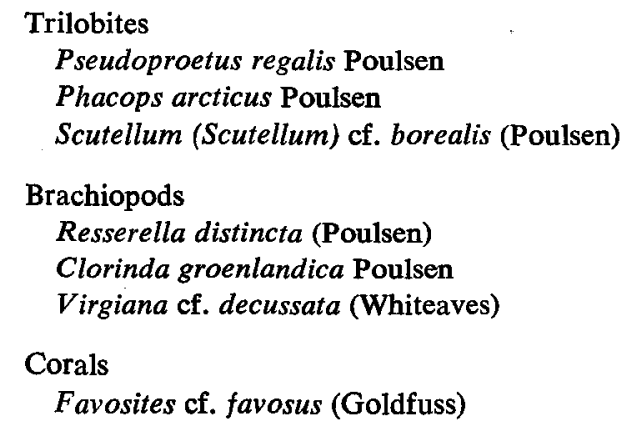

\section{Locality F5, west coast of Citronens Fjord}

GGU samples 53557-53562

The fossils were collected from an intraformational limestone conglomerate layer within a folded, calcareous-sandstone-siltstone-shale succession. From a small poorly-preserved coral-crinoid-braciopod fauna the following corals are identified:

Favosites sp.

Cystiphyllum? sp.

Age of the fauna

The fauna from locality F4 is of early Silurian age. Favosites cf. favosus (Goldfuss) is the same species as described and figured from the Offley Island Formation in western North Greenland by C. Poulsen (1941), and Clorinda groenlandica is known from this formation as well as from the subjacent Cape Schuchert Formation (see C. Poulsen, 1934, 1943). Virgiana decussata is an early Silurian Canadian species. The other species listed are only known from the Cape Schuchert Formation. A correlation with the fauna of the Cape Schuchert Formation is supported in the Peary Land samples of indeterminate species of trilobites and brachiopods belonging to Upper Ordovician-Lower Silurian genera. The only major difference is the occurrence of gastropods in the Frederick E. Hyde Fjord area; gastropods have not been recorded from the Cape Schuchert Formation. Genera such as Holopea, Donaldiella? and Euomphalus are present, but the state of preservation of the internal moulds does not permit any assignment to species.

The poor state of preservation of the material from locality F5 prevents reliable conclusions being made as regards age but the stratigraphy in Citronens Fjord 
is correlatable with that at locality $\mathrm{F} 4$ and the fauna is possibly of the same age. The middle part of the Cape Schuchert Formation in western North Greenland contains graptolites from Elles \& Wood's graptolite zone 20 belonging to the late Middle Llandovery (Lower Niagaran in the North American standard) and the fauna from Frederick E. Hyde Fjord is concluded to be of the same age.

\section{References}

Berry, W. B. N. 1960: Graptolite faunas of the Marathon region, West Texas. Univ. Tex. Publs, 6005, $129 \mathrm{pp}$.

Dawes, P. R. \& Soper, N. J. 1970: Geological investigations in northern Peary Land. Rapp. Grønlands geol. Unders. 28, 9-15.

Dewey, J. F., Rickards, R. B. \& Skevington, D. 1970: New light on the age of the Dalradian deformation and metamorphism in western Ireland. Norsk geol. Tidsskr. 50, 19-44.

Kindle, C. H. \& Whittington, H. B. 1958: Stratigraphy of the Cow Head region, western Newfoundland. Bull. geol. Soc. Am. 69, 315-342.

Poulsen, C. 1934: The Silurian faunas of North Greenland. I. The fauna of the Cape Schuchert Formation. Meddr Grønland 72, 2 Afd. (1), 46 pp.

Poulsen, C. 1941: The Silurian faunas of North Greenland. II. The fauna of the Offley Island Formation. Part 1: Coelenterata. Meddr Grønland 72, 2 Afd. (2), 28 pp.

Poulsen, C. 1943: The Silurian faunas of North Greenland. II. The fauna of the Offley Island Formation. Part 2: Brachiopoda. Meddr Grønland 72, 2 Afd. (3), 60 pp.

Rickards, R. B. 1972: The Ordovician graptolite genus Paraglossograptus Mu. Geol. Mag. 109, 99-113.

Skevington, D. 1968: British and North American Lower Ordovician correlation: discussion. Bull. geol. Soc. Am. 79, 1259-1264.

Institut for historisk Geologi og Palceontologi, University of Copenhagen,

$\emptyset$ stervoldgade 10 , 1350 Copenhagen $K$.

\section{MARINE GEOPHYSICAL SURVEY BETWEEN $68^{\circ} 30^{\prime} \mathrm{N}$ AND $73^{\circ} 30^{\prime} \mathrm{N}$, WEST GREENLAND}

\section{Leslie R. Denham}

An offshore geophysical programme was carried out during the summer to extend the mapping of the Cretaceous-Tertiary onshore sedimentary basin in West Greenland to the adjacent fjord areas, and to investigate the relationship of the onshore sediments and volcanics to offshore sediments to the west (Ross \& Henderson, 1973).

Between 4th July and 2nd August a four-man party led by the writer and Birger Larsen (Danmarks Tekniske Højskole) on the chartered Norwegian sealer 